\title{
Numerical simulation of far-field tsunamis using the linear Boussinesq equation -The 1998 Papua New Guinea Tsunami-
}

\author{
by
}

Yuichiro Tanioka

Meteorological Research Institute, Tsukuba, Japan

(Received December 21, 1999 ; Revised May 16, 2000)

\begin{abstract}
The dispersion effect is not negligible in the numerical simulation of far-field tsunamis propagating through deep oceans. Imamura et al. (1990) introduced a technique in which the discretization error in the finite difference equation of the linear long wave equation was used to approximate the physical dispersion term. The technique is widely accepted to compute transPacific tsunamis caused by great earthquakes $(\mathrm{Mw}>8)$. However, the technique has never been applied to compute tsunamis caused by smaller earthquakes $(\mathrm{Mw}<7)$ because the approximation may break down. In order to compute the tsunami caused by the 1998 Papua New Guinea earthquake (Mw 7.1), we numerically solve the linear Boussinesq equation, which includes the physical dispersion term, using an implicit scheme. For comparison, we also compute the tsunami using Imamura's technique. The comparison of the computed waveforms at the ocean bottom pressure gauge off Boso (BS3-OBP) from the two numerical simulations indicates that the linear Boussinesq equation should be used to simulate the tsunami waveform more accurately, especially the later phase of tsunami waveforms. We also found that the observed tsunami that was originally generated by the 1998 Papua New Guinea earthquake and recorded at BS3-OBP was a ridge wave. The ridge wave was enhanced by the shallow water region around the Izu-Bonin Islands.
\end{abstract}

\section{Introduction}

For distant tsunamis, the linear Boussinesq equation should be used in numerical simulations because the dispersion has a large effect on the waveform. However, the finite difference equation of the linear Boussinesq equation cannot be expressed by an explicit scheme and requires much computational time. Recently, Imamura et al. (1990) introduced a new technique, in which the discretization error in the finite difference equation of the linear long wave theory was used to replace the physical dispersion term in the linear Boussinesq equation. In order to use the technique, the grid size must be carefully chosen to make the effects of the

(C) 2000 by the Meteorological Research Institute discretization and the physical dispersion equal. Imamura et al. (1990) show that the choice of the grid size can be evaluated using the Imamura number, Im, defined as

$$
\operatorname{Im}=\Delta x \sqrt{1-\left(\sqrt{g d} \frac{\Delta t}{\Delta x}\right)^{2}} / 2 d
$$

where $\Delta x$ is the grid size, $\Delta t$ is the time step, $g$ is the acceleration of gravity, and $d$ is water depth. Im must be about 1.0 to simulate the linear Boussinesq equation by using the finite difference computation of the linear long wave equation. Note, Im in Eq. (1) mainly depends on the grid size $(\Delta x)$ and water depth $(d)$, and not much on the time step $(\Delta t)$. In order to simulate a large tsunami that propagates through the Pacific, we typically use a grid size of 5 minutes and the time step of 5 seconds to satisfy the 
stability condition. Using Eq. (1), Im is 1.15 in the $\mathrm{N}-\mathrm{S}$ direction, assuming that the average water depth in the Pacific ocean is $4000 \mathrm{~m}$. In the $\mathrm{E}-\mathrm{W}$ direction, Im varies with latitude and is $0.73-1.15$ within the latitudes between $50^{\circ}$ and $0^{\circ}$. These show that $\mathrm{Im}$ is close to 1.0 and indicate that the 5 minute grid system on the Pacific ocean makes the effect of the discretization in the finite difference computation and the physical dispersion similar. Note, that Im becomes much larger than 1.0 near shore because of the shallow water, although most parts of the tsunami propagate through the deep Pacific ocean.

The above technique was widely used for the numerical simulation of tsunamis caused by great earthquakes $(\mathrm{Mw}>8)$ that propagated through the Pacific ocean (e.g. Johnson, 1998; Tanioka and Gonzalez, 1998). However, the technique has never been applied to compute tsunamis caused by smaller earthquakes $(\mathrm{Mw}<7)$ because of two limitations. One limitation is that the grid size of 5 minutes (about $9 \mathrm{~km}$ ) becomes too coarse to describe the deformation pattern of the earthquakes. The other limitation is that the effect of the physical dispersion becomes large and the Im number in Eq. (1) must be more precisely 1.0 to use the discretization in the finite difference computation of the linear long wave equations.

In this paper, we numerically computed the tsunami caused by the 1998 Papua New Guinea earthquake (Ms 7.1) by solving the linear Boussinesq equation, directly. We also numerically computed the tsunami using the technique proposed by Imamura et al.(1990). We, then compared the computed tsunami waveforms from both methods with the observed waveforms at the ocean bottom pressure gauge off Boso (BS3-OBP). We analyze differences between the two computed waveforms. In addition, the generation mechanism of the large tsunami at the BS3-OBP is discussed.

\section{Method of Solving the Linear Boussinesq Equation}

\subsection{Governing Equations}

The governing equations are the following linear Boussinesq equations with the Coriolis force in the spherical coordinate system (longitude $\varphi$ and colatitude $\theta$ ) :

$$
\begin{aligned}
& \frac{\partial h}{\partial t}=-\frac{1}{R \sin \theta}\left[\frac{\partial Q_{\Psi}}{\partial \varphi}+\frac{\partial}{\partial \theta}\left(Q_{\theta} \sin \theta\right)\right] \\
& \frac{\partial Q_{\varphi}}{\partial t}=-\frac{g d}{R \sin \theta} \frac{\partial h}{\partial \varphi}-f Q_{\theta} \\
& \quad+ \frac{1}{3 R \sin \theta} \frac{\partial}{\partial \varphi}\left[d^{2} \frac{1}{R \sin \theta}\left[\frac{\partial^{2} Q_{\varphi}}{\partial t \partial \varphi}+\frac{\partial^{2}}{\partial t \partial \theta}\left(Q_{\theta} \sin \theta\right)\right]\right](3) \\
& \frac{\partial Q_{\theta}}{\partial t}=-\frac{g d}{R} \frac{\partial h}{\partial \theta}+f Q_{\varphi} \\
& \quad+\frac{1}{3 R} \frac{\partial}{\partial \theta}\left[d^{2} \frac{1}{R \sin \theta}\left[\frac{\partial^{2} Q_{\varphi}}{\partial t \partial \varphi}+\frac{\partial^{2}}{\partial t \partial \theta}\left(Q_{\theta} \sin \theta\right)\right]\right]
\end{aligned}
$$

where $R$ is the radius of the Earth, $g$ is the acceleration of gravity, $d$ is the water depth, $f$ is the Coriolis parameter, $h$ is the height of the water displaced from the equilibrium position, $Q_{\varphi}\left(=u_{\varphi} d\right)$ and $Q_{\theta}\left(=u_{\theta} d\right)$ are the flow rates in the $\varphi^{-}$and $\theta$-directions, and $u_{\varphi}$ and $u_{\theta}$ are the average velocities in the $\varphi^{-}$and $\theta$-directions. Using Eq. (2), Eqs. (3) and (4) were transformed to

$$
\frac{\partial Q_{\varphi}}{\partial t}=-\frac{g d}{R \sin \theta} \frac{\partial h}{\partial \varphi}-f Q_{\theta}-\frac{1}{3 R \sin \theta} \frac{\partial}{\partial \varphi}\left[d^{2} \frac{\partial^{2} h}{\partial t^{2}}\right]
$$

and

$$
\frac{\partial Q_{\theta}}{\partial t}=-\frac{g d}{R} \frac{\partial h}{\partial \theta}+f Q_{\varphi}-\frac{1}{3 R} \frac{\partial}{\partial \theta}\left[d^{2} \frac{\partial^{2} h}{\partial t^{2}}\right] .
$$

\subsection{Numerical Scheme}

The Alternating Direction Implicit (ADI) finite difference scheme with a double sweep algorithm (see Kabiling and Sato, 1993) was used to solve Eqs. (2), (5), and (5). A staggered grid was used with $\Delta \varphi$ and $\Delta \theta$ as the grid spacing in the $\varphi^{-}$and $\theta$-directions, and $\Delta t$ as the time step.

For the first sweep, the finite difference formulations of Eqs. (2), (5), and (5) at a grid point ( $i, j)$ and time $t=n \Delta t$ are

$$
\begin{aligned}
& \frac{h_{i, j}^{(n+1 / 2) \Delta t}-h_{i, j}^{n \Delta t}}{\Delta t / 2}=-\frac{1}{R \sin \theta_{j}} \frac{Q_{q i+1, j}^{(n+1 / 2) \Delta t}-Q_{\varphi, i j}^{(n+1 / 2) \Delta t}}{\Delta \varphi} \\
& -\frac{1}{R \sin \theta_{j}} \frac{Q_{\theta i, j+1}^{n \Delta t} \sin \theta_{j+1}-Q_{\theta i, j}^{n \Delta t} \sin \theta_{j}}{\Delta \theta} \\
& \frac{Q_{\varphi, j}^{(n+1 / 2) \Delta t}-Q_{\varphi i, j}^{n \Delta t}}{\Delta t / 2}=-\frac{g d_{i, j}}{R \sin \theta_{j}} \frac{h_{i, j}^{(n+1 / 2) \Delta t}-h_{i-1, j}^{(n+1 / 2) \Delta t}}{\Delta \varphi}-f Q_{\theta_{t, j}}^{n \Delta t} \\
& -\frac{1}{3 R \sin \bar{\theta}_{j}}\left[\frac{h_{i, j}^{(n+1 / 2) \Delta t}-2 h_{i, j}^{n \Delta t}+h_{i, j}^{(n+1 / 2) \Delta t}}{\Delta \varphi(\Delta t / 2)^{2}} d_{i, j}^{2}\right. \\
& \left.-\frac{h_{i-1, j}^{(n+1 / 2) \Delta t}-2 h_{i-1, j}^{n t}+h_{i-1, j}^{(n-1 / 2) \Delta t}}{\Delta \varphi(\Delta t / 2)^{2}} d_{i-1, j}^{2}\right] \\
& \frac{Q_{\theta i, j}^{(n+1 / 2) \Delta t}-Q_{\theta i, j}^{n t}}{\Delta t / 2}=-\frac{g d_{i, j}}{R} \frac{h_{i, j}^{(n+1 / 2) \Delta t}-h_{i, 1-j}^{(n+1 / 2) \Delta t}}{\Delta \theta}+f Q_{q i, j}^{n A t} \\
& -\frac{1}{3 R}\left[\frac{h_{i, j}^{(n+1 / 2) \Delta t}-2 h_{i, j}^{n A t}+h_{i, j}^{(n-1 / 2) \Delta t}}{\Delta \theta(\Delta t / 2)^{2}} d_{i, j}^{2}\right. \\
& \left.-\frac{h_{i, j-1}^{(n+1 / 2) \Delta t}-2 h_{i, j-1}^{n \Delta t}+h_{i, j-1}^{(n-1 / 2) \Delta t}}{\Delta \theta(\Delta t / 2)^{2}} d_{i, j-1}^{2}\right]
\end{aligned}
$$

Equations (7), (8), and (9) can be written in the following forms with coefficients $A, B, C$, and Ds : 


$$
\begin{aligned}
& A_{1} \cdot Q_{\varphi i, j}^{(n+1 / 2) \Delta t}+B_{1} \cdot h_{i, j}^{(n+1 / 2) \Delta t}+C_{1} \cdot Q_{\varphi i+1, j}^{(n+1 / 2) \Delta t}=D_{1} \\
& A_{2} \cdot h_{i-1, j}^{(n+1 / 2) \Delta t}+B_{2} \cdot Q_{\varphi, j}^{(n+1 / 2) \Delta t}+C_{2} \cdot h_{i, j}^{(n+1 / 2) \Delta t}=D_{2} \\
& A_{3} \cdot h_{i, j-1}^{(n+1 / 2) \Delta t}+B_{2} \cdot Q_{\theta i, j}^{(n+1 / 2) \Delta t}+C_{3} \cdot h_{i, j}^{(n+1 / 2) \Delta t}=D_{3}
\end{aligned}
$$

Unknown quantities, $Q_{\varphi}$ and $h$, at $t=(n$ $+1 / 2) \Delta t$ can be determined by solving the Eqs. (10) and (11) using the implicit scheme. Unknown quantities, $Q_{\theta}$ at $t=(n+1 / 2) \Delta t$, can then be determined by solving Eq. (12).

For the second sweep, the finite difference formulation of Eq. (2) at a grid point $(i, j)$ and time $t=(n+1 / 2) \Delta t$, becomes

$$
\begin{aligned}
\frac{h_{i, j}^{(n+1) \Delta t}-h_{i, j}^{(n+1 / 2) \Delta t}}{\Delta t / 2}= & -\frac{1}{R \sin \theta_{j}} \frac{Q_{\varphi i+1, j}^{(n+1 / 2) \Delta t}-Q_{\varphi, j}^{(n+1 / 2) \Delta t}}{\Delta \varphi} \\
& -\frac{1}{R \sin \theta_{j}} \frac{Q_{\theta i, j+1}^{(n+1) \Delta t} \sin \theta_{j+1}-Q_{\theta i, j}^{(n+1) \Delta t} \sin \theta_{j}}{\Delta \theta}
\end{aligned}
$$

The finite difference formulations of Eqs. (5) and (5) are the same as those of Eqs. (8) and (9), although time $t$ needs to change from $n \Delta t$ to $t=$ $(n+1 / 2) \Delta t$,. Equation (13) and the finite difference formulations of Eqs. (5), and (5) can be written in the following forms with coefficients A', B', C', and D's :

$$
\begin{aligned}
& A_{1}^{\prime} \cdot Q_{\varphi, j}^{(n+1) \Delta t}+B_{1}^{\prime} \cdot h_{i, j}^{(n+1) \Delta t}+C_{1}^{\prime} \cdot Q_{\theta i, j+1}^{(n+1) \Delta t}=D_{1}^{\prime} \\
& A_{2}^{\prime} \cdot h_{i-1, j}^{(n+1) \Delta t}+B_{2}^{\prime} \cdot Q_{\varphi i, j}^{(n+1) \Delta t}+C_{2}^{\prime} \cdot h_{i, j}^{(n+1) \Delta t}=D_{2}^{\prime} \\
& A_{3}^{\prime} \cdot h_{i, j-1}^{(n+1) \Delta t}+B_{3}^{\prime} \cdot Q_{\theta i, j}^{(n+1) \Delta t}+C_{3}^{\prime} \cdot h_{i, j}^{(n+1) \Delta t}=D_{3}^{\prime}
\end{aligned}
$$

Unknown quantities, $Q_{\theta}$ and $h$, at $t=(n+1) \Delta t$, can be determined by solving the Eqs. (14) and (15) using the implicit scheme. Unknown quantities, $Q_{\varphi}$, can then be determined by solving Eq. (15). Using this numerical scheme, we simulate the 1998 Papua New Guinea tsunami.

\section{Numerical simulation of the 1998 Papua New Guinea tsunami}

\subsection{Simulation Conditions}

The computational area is shown in Figure 1. The open boundary condition at the edge of the computational area and the total reflection boundary at the shoreline are used for computation. The grid spacing is $1 \mathrm{~min} \times 1 \mathrm{~min}$ for the numerical simulation using the linear Boussinesq equation and $5 \mathrm{~min} \times 5 \mathrm{~min}$ for the numerical simulation using the technique introduced by Imamura et al. (1990). The grid bathymetry data was produced by interpolating the global digital bathymetry data (Smith and Sandwell, 1997) which is available through the WWW browser. The fault parameters of the Papua New

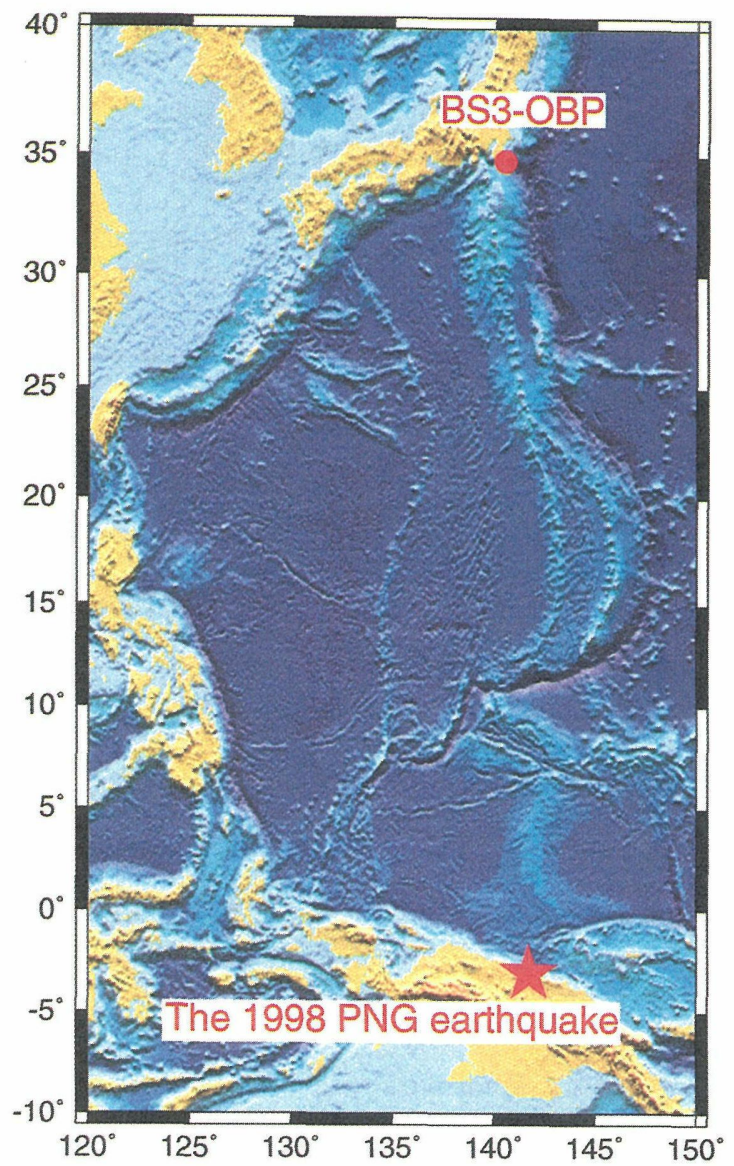

Fig. 1 Tsunami computational area. Red circle shows the location of the ocean bottom pressure gauge off Boso. Red star represents the epicenter of the 1998 Papua New Guinea earthquake.

Guinea earthquake determined by Tanioka (1999) are shown in Figure 2. and Table 1. Those parameters were used to compute the vertical displacement at the ocean bottom caused by the earthquake using Okada's (1985) formulas. The vertical displacement at the ocean bottom was used as an initial condition of the tsunami.

\subsection{Tsunami Waveform Data}

We only used the tsunami waveform observed at the ocean bottom pressure gauge at the water depth of 1,912 meters off Boso (BS3-OBP) which is described by Okada (1995), in detail. The tsunami generated by the 1998 Papua New Guinea earthquake was observed at several tide gauges in Japan. However, the later phase of the tsunami waveforms at tide gauges are significantly affected by the near-shore bathymetry. The near-shore bathymetry is complicated and cannot be described by the grid spacing of $1 \mathrm{~min}$. X $1 \mathrm{~min}$. Therefore, we did not use the tsunami waveforms at tide gauges in this study. 


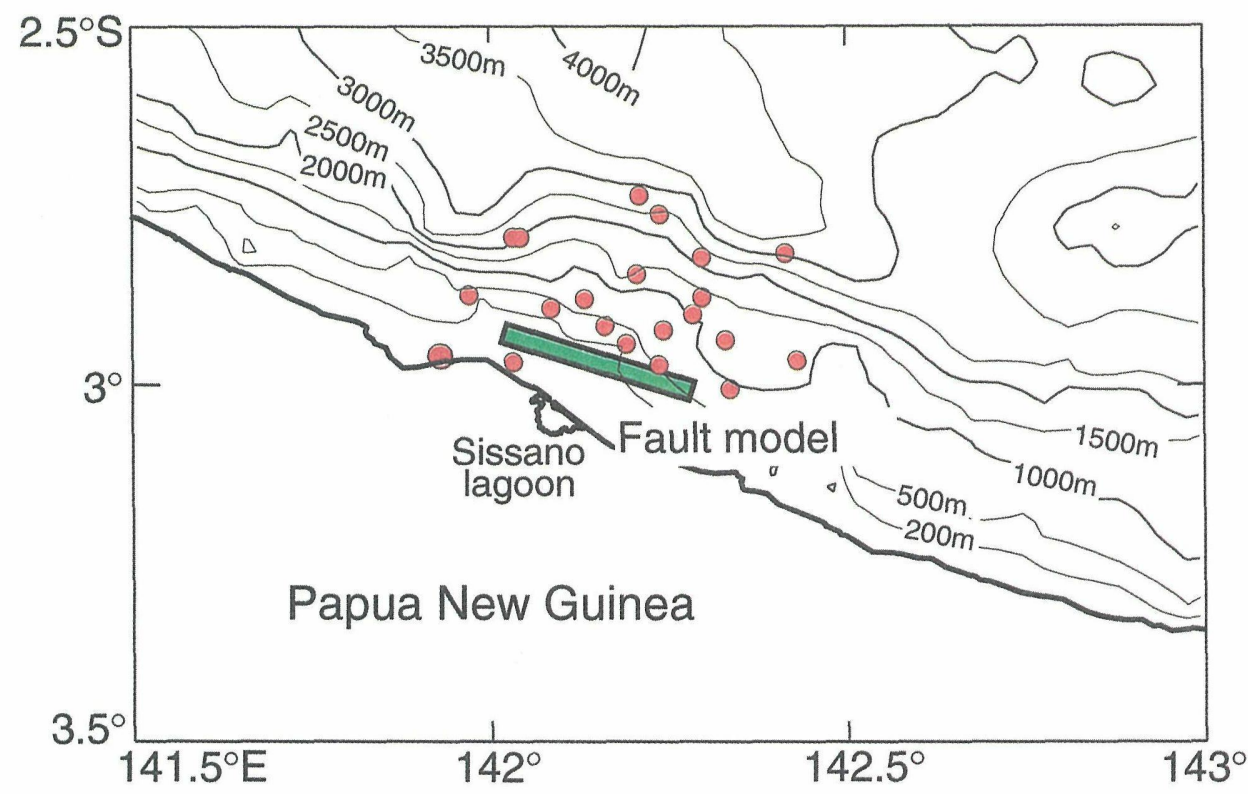

Fig. 2 The fault mode for the 1998 Papua New Guinea earthquake determined by Tanioka (1999). Green rectangle shows the location of the fault model. Solid red circles are the aftershocks determined by Hurukawa (1999).

Table 1. Fault parameters determined by Tanioka (1999)

\begin{tabular}{ll}
\hline strike & $287^{\circ}$ \\
dip & $75^{\circ}$ \\
rake & $90^{\circ}$ \\
\hline fault length & $35 \mathrm{~km}$ \\
fault width & $15 \mathrm{~km}$ \\
slip & $2.7 \mathrm{~m}$ \\
$\mathrm{M}_{0}$ & $3.7 \times 10^{19} \mathrm{Nm}$ \\
\hline
\end{tabular}

\subsection{Comparison of the two Methods}

The computed tsunami waveforms at the BosoOBP using the two methods, the linear Boussinesq equation and the linear long wave equation with Imamura's (1990) technique, are compared with the observed waveforms in Figure 3. The earthquake occurred at 8:49 (GMT) on 17 July 1998. The first tsunami wave arrived at around 15 hours (GMT) for the computed tsunami waveforms from both methods. The amplitudes of the first waves computed from both methods are also similar. The tsunami wave was clearly observed at around 16 hours (GMT) which is about one hour after the first computed tsunami wave. The larger tsunami wave was also computed at around 16 hours (GMT) from both methods. The amplitude of the computed tsunami wave from the linear Boussinesq equation is close to the observed wave. However, the computed tsunami from the linear long wave equations with Imamura's technique underestimates the tsunami observed at around 16 hours. This indicates that it is

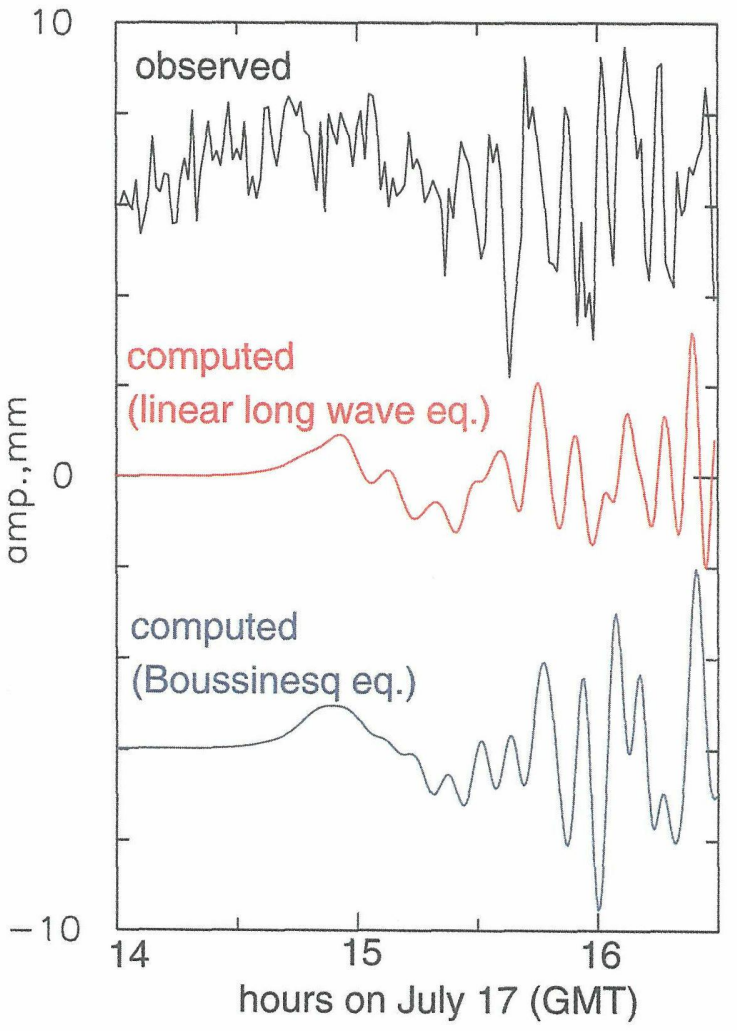

Fig. 3 Comparison of observed and two computed tsunami waveforms at BS3-OBP. A black line is the observed waveforms. A red line is the computed waveforms using the linear long wave equation with Imamura's (1990) technique. A blue line is the computed waveforms using the linear Boussinesq equation. 
better to solve the linear Boussinesq equation in order to compute the later phase of tsunami accurately.

\subsection{Generation Mechanism of the Large Later} Tsunami at Boso

Snapshots of the computed tsunami around the Izu-Bonin Islands using the linear Boussinesq equation are shown in Figures 4, 5, and 6 ; details of the tsunami propagation are shown in the Appendix. At 300 minutes after the earthquake (Figure 4), the tsunami wave front arrives at the south of the Izu-Bonin Islands. When the tsunami wave front hits the shallow water area around the Izu-Bonin Islands, the wave front bends and surrounds the shallow area (Figure 4). This indicates that tsunami energy converges to the shallow area. Also, the wavelength of the first wave east of the Izu-Bonin Islands becomes longer than that west of the Islands. At 340-350 minutes after the earthquake, the large tsunamis were generated in the shallow water area around the Izu-Bonin Islands. At 350 minutes after the earthquake (Figure 5), the longer wavelength tsunami arrives at the BS3-OBP shown in Figure 4. At the same time, the large tsunami generated in the shallow water area by energy convergence propagates slowly to the north. At 380 minutes after the earthquake, the longer wavelength tsunami has already passed above the BS3 -OBP, but the large tsunami is still in shallow water area and propagates to the north. Finally, at 420 minutes after the earthquake, 15: 49 (GMT), the large tsunami arrives at the BS3-OBP.

The above results show that the observed tsunami arriving at around 16 hours (GMT) at the ocean pressure gauge off Boso (Figure 3) was caused by the existence of the shallow water area around the Izu-Bonin Islands. The large amplitude tsunami on the shallow water area forms a kind of secondary source, then starts propagating along the shallow water area. This type of tsunami caused by a ridge system was also generated by the 1990 Mariana earthquake (Satake et al., 1992) and the 1995 Irian Jaya earthquake (Koshimura et al., 1997). They called it a ridge wave.

\section{Conclusions}

The comparison of the computed waveforms at Boso-OBP indicates that the numerical simulation using the linear long wave equation with Imamura' s (1990) technique for the 1998 Papua New Guinea earthquake is acceptable for the first tsunami wave to arrive, but not for later waves. In order to com- pute the later tsunami wave more accurately, the linear Boussinesq equation should be used. The observed tsunami at Boso-OBP was a ridge wave that was enhanced by the shallow water region around the Izu-Bonin Islands.

\section{Acknowledgments}

We are grateful to Mr. Masami Okada and Mr. Kenji Kanjo for their helpful discussions, and would also like to thank Dr. Shunichi Koshimura for providing his papers, and Mr. Yasuo Sekita for his helpful comments.

\section{References}

Hurukawa, N., 1999, Aftershocks and the fault plane of the 1998 Papua New Guinea earthquake determined by data of the international data center of CTBT, Zisin 2, 95-100.

Imamura, F., N. Shuto, and C. Goto, 1990, Study on the numerical simulation of the transoceanic propagation of tsunami, Zisin 2, 389-402 (in Japanese).

Johnson, J. M., 1998, Heterogeneous coupling along Alaska-Aleutians as inferred from tsunami, seismic, and geodetic inversions, Advance in Geophysics, 39, 1-110.

Kabiling, M. B., and S. Sato, 1993, Two-dimensional nonlinear dispersive wave-current and three dimensional beach deformation model, Coastal Eng. in Japan, 35, 195-212.

Koshimura, S., Imamura, F., and Shuto, N, 1997, Study on boundary waves excited on oceanic ridges, Proc. of 44th. Japan Conf. on Coastal Eng., 305-310 (in Japanese).

Okada, M., 1995, Tsunami Observation by ocean bottom pressure gauge, in $\mathrm{Y}$. Tsuchiya and $\mathrm{N}$. Shuto (ed.), Tsunami : Progress in prediction, Disaster prevention and Warning, Kluwer Academic Publishers, 287-303.

Okada, Y., 1985, Surface deformation due to shear and tensile faults in a half-space, Bull. Seismo. Soc. Am., 75, 1135-1154.

Satake, K., Y. Yoshida, and K. Abe, 1992, Tsunami from the Mariana earthquake of April 5, 1990 : Its abnormal propagation and implications for tsunami potential from outer-rise earthquakes, Geophys. Res. Lett., 19, 301-304.

Smith, W. H., and D. T., Sandwell, 1997, Global sea floor topography from satellite altimetry and ship depth soundings, Science, 277, 1955-1952.

Tanioka, Y., 1999, Analysis of the far-field tsunamis generated by the 1998 Papua New Guinea earth- 

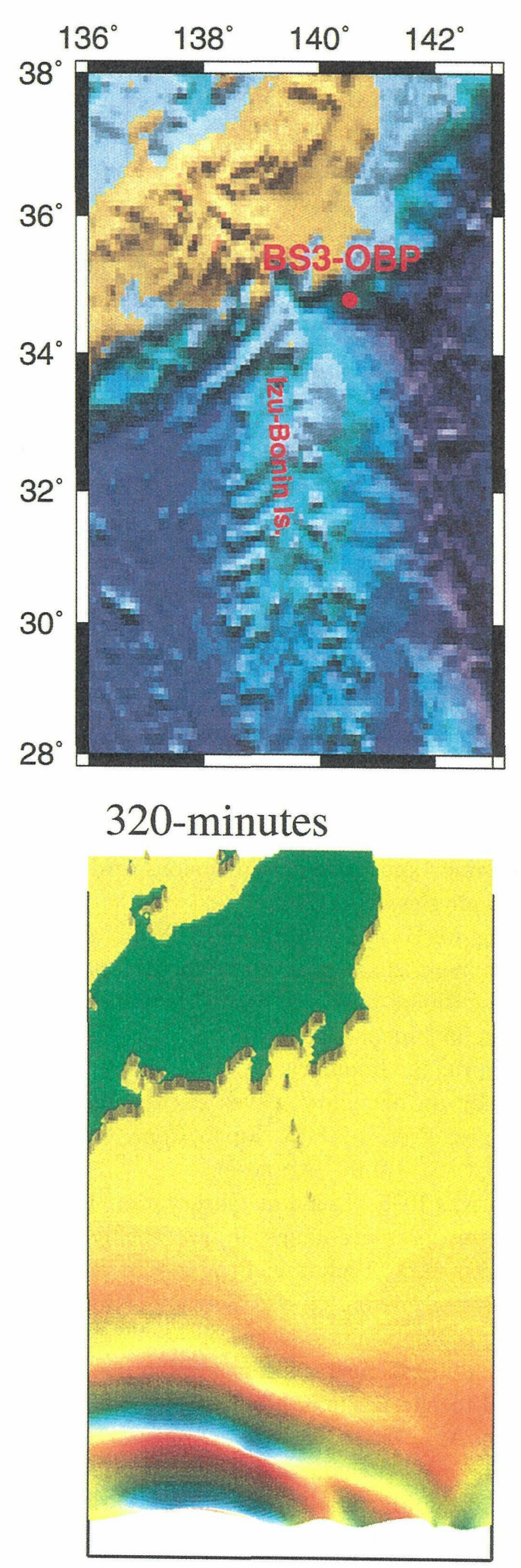

300-minutes

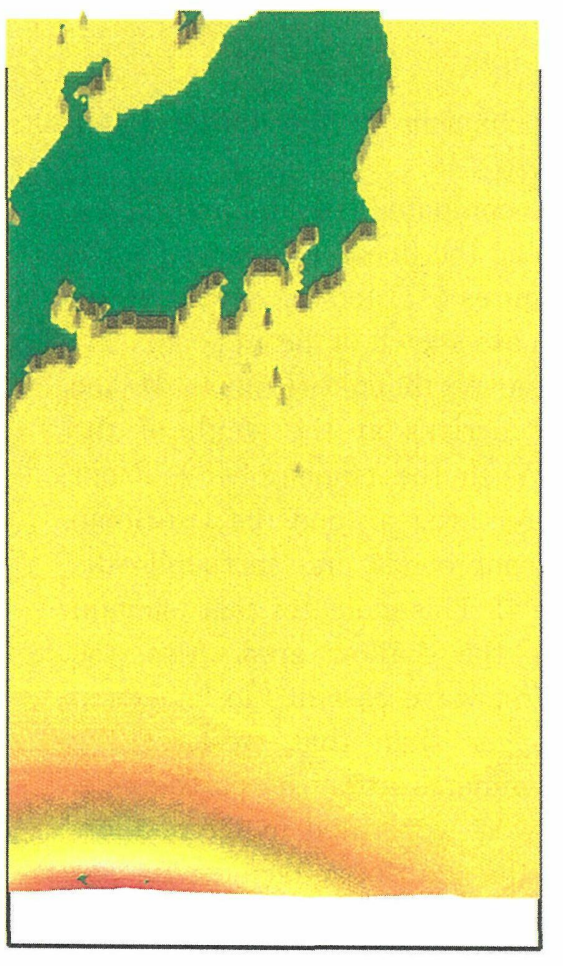

\section{0-minutes}

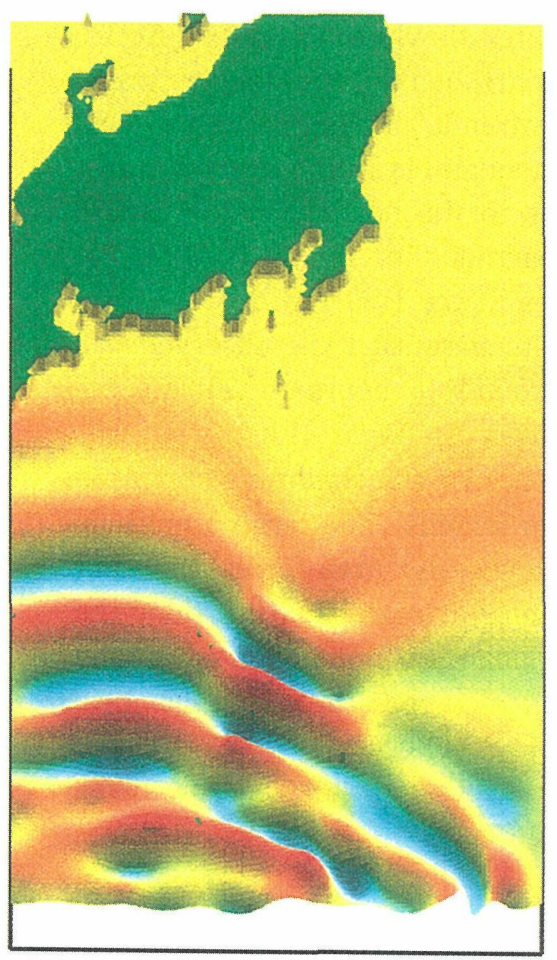

$\mathrm{mm}$

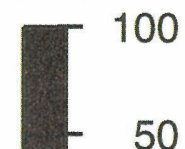

20

10

5

2

0

\section{$-2$}

$-5$

$-10$

$-20$

$-50$

$-100$

Fig. 4 Bathymetry map near the Izu-Bonin Islands and three snapshots of the computed tsunami using the linear Boussinesq equation. The three snapshots are for 300,320 , and 340 minutes after the origin time of the earthquake. 

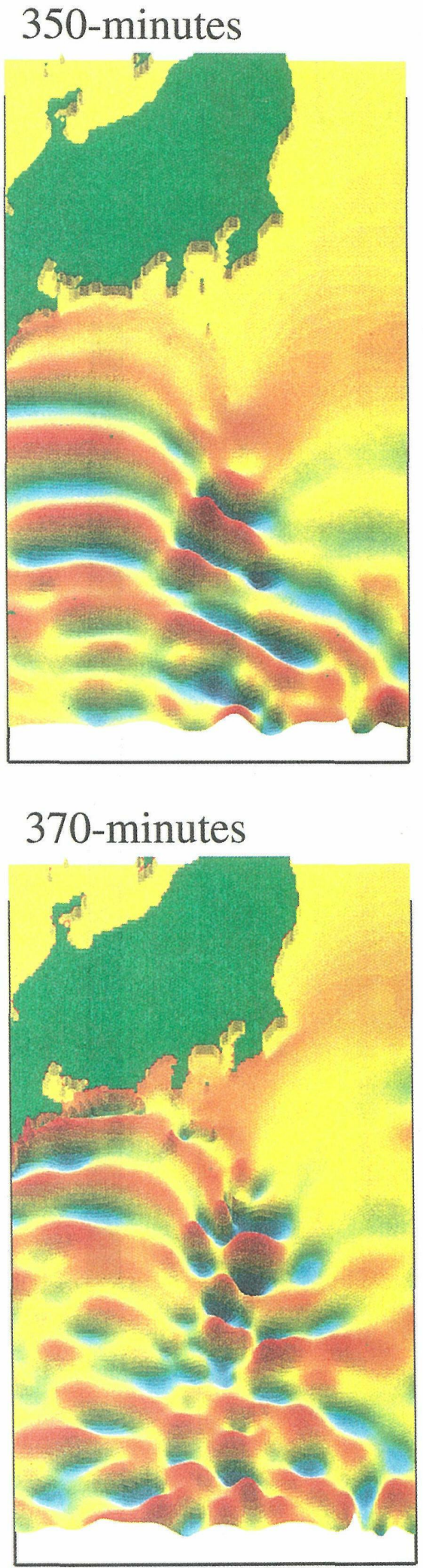

360-minutes

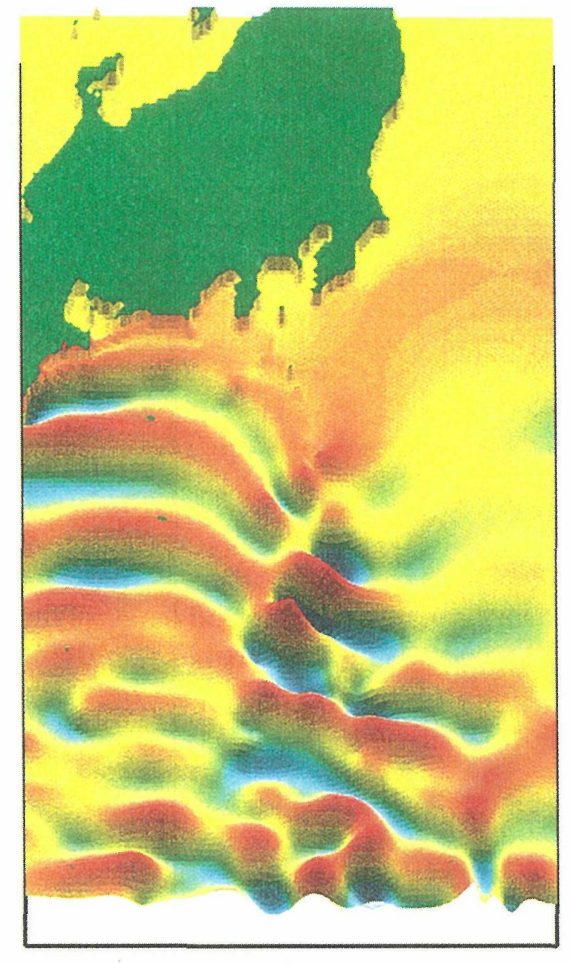

\section{0-minutes}

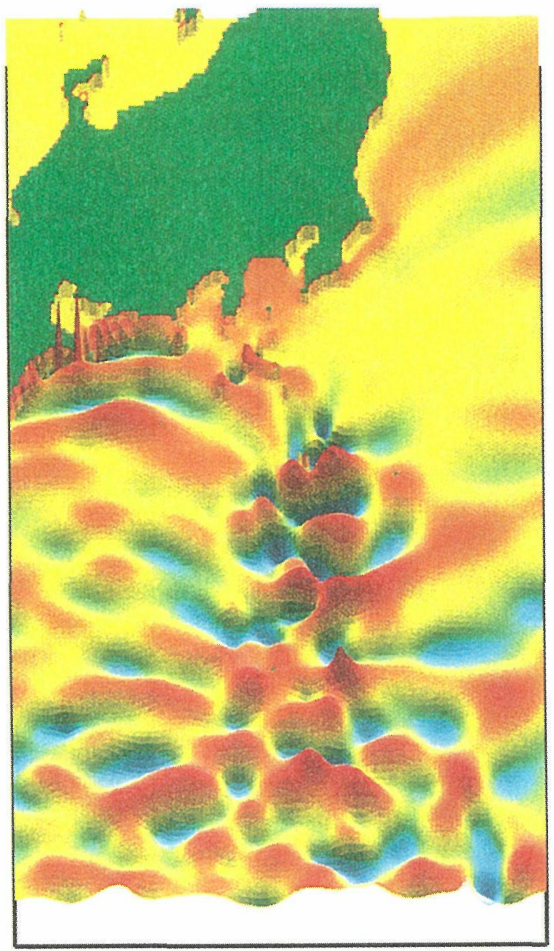

$\mathrm{mm}$

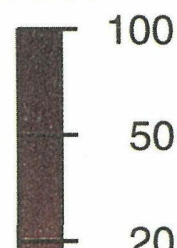

$-10$

5

2

0

$-2$

$-5$

$-10$

$-20$

$-50$

Fig. 5 Four snapshots of the computed tsunami at 350, 350, 370, and 380 minutes after the origin time of the earthquake. 


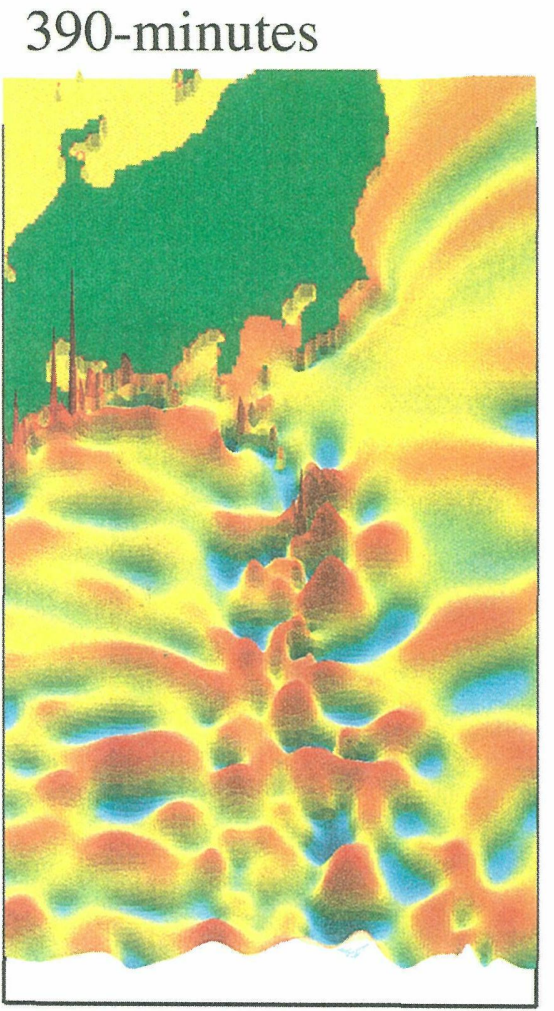

\section{0-minutes}

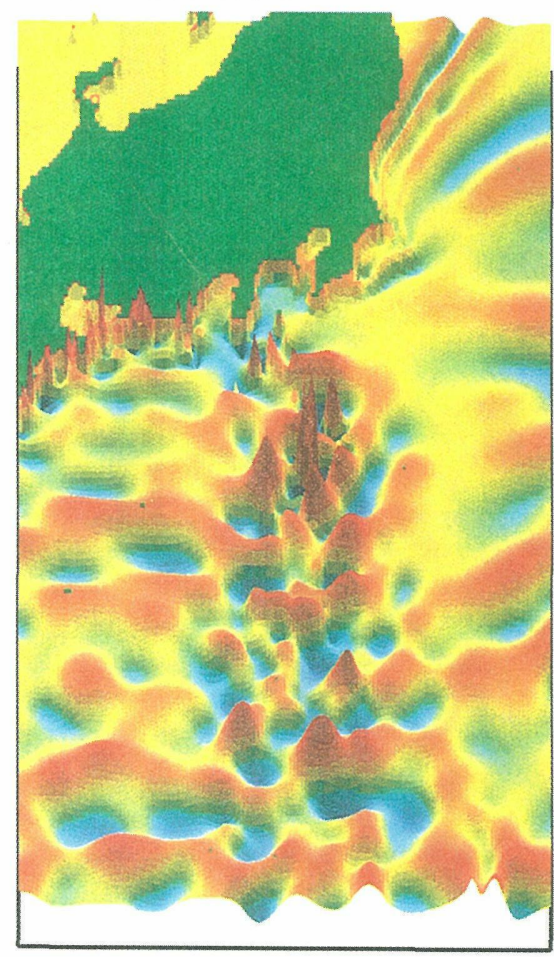

400-minutes

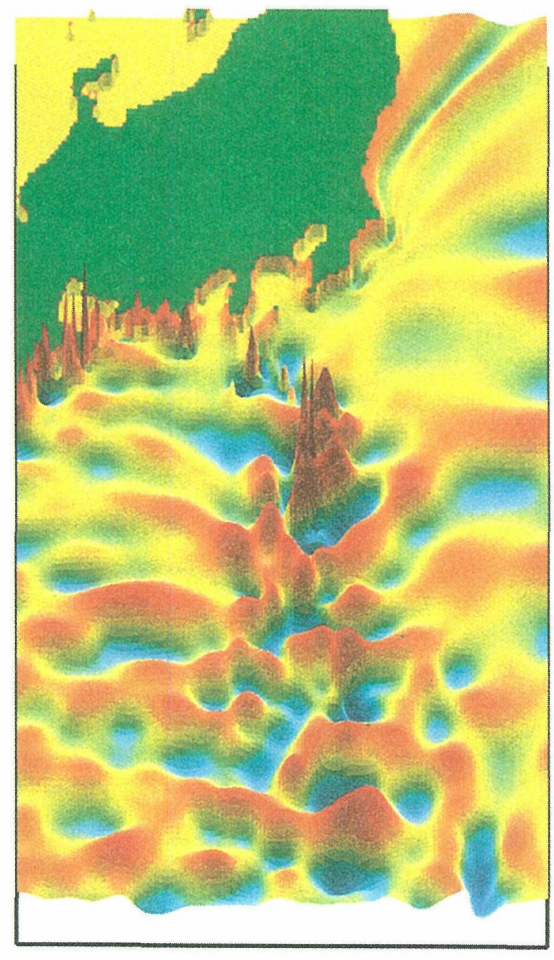

420-minutes

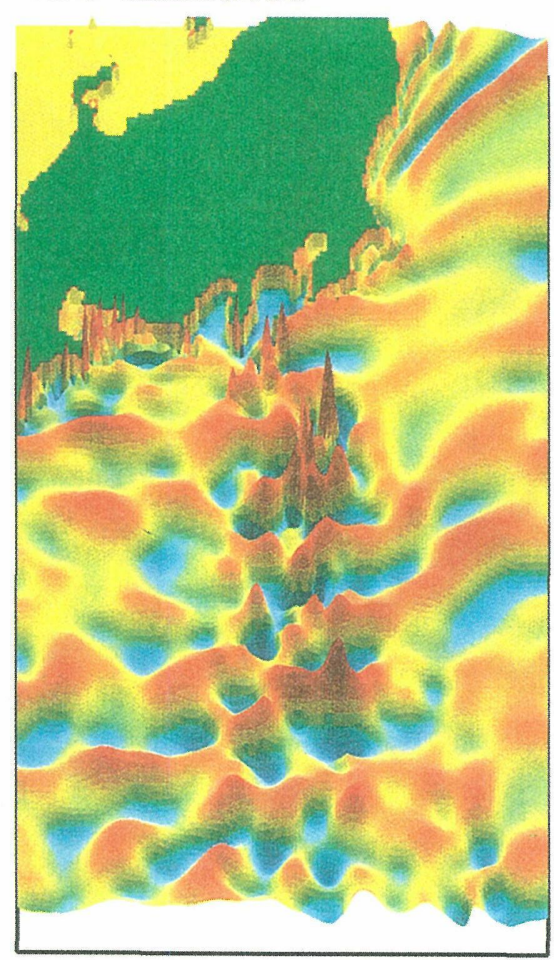

$\mathrm{mm}$

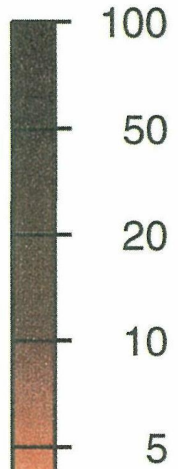

5
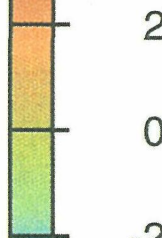

$-5$

$-100$

Fig. 6 Four snapshots of the computed tsunami at 390, 400, 410, and 420 minutes after the origin time of the earthquake. 
quake, Geophys. Res. Lett., 26, 3393-3395.

Tanioka, Y., and F. I. Gonzalez, 1998, The Aleutian earthquake of the June 10, 1995 (Mw 7.9) ruptured parts of both the Andreanof and Delarof segments, Geophys. Res. Lett., 25, 2245-2248.

\section{Appendix}

We made a Quick Time Movie showing the tsunami propagation near the Izu-Bonin Islands. The movie is available on CD-ROM. Please contact the following address to obtain the CD-ROM.

Yuichiro Tanioka

Seismology and Volcanology Department, Meteorological Research Institute

1-1 Nagamine Tsukuba, 305-0052, Japan. e-mail: ytanioka@mri-jma.go.jp

\section{線形 Boussinesq 式を用いた遠地津波の数値計算 \\ -1998 年パプアニューギニア津波の場合一}

\section{谷岡勇市郎}

遠地津波の数值計算では波数分散効果を無視できない。Imamura（1990）は線形長波理論を差分法で計算する場合に発 生する数値分散を物理的な波数分散と同じくする事により，線形長波の式を解きながら波数分散効果を取り入れる方法を 紹介した。この方法は巨大地震により発生した津波の数値計算に広く一般に使われている。しかし，この方法は大きな格 子間隔を必要とし，M 7 クラス以下の地震により発生する津波には適用できない可能性が高い。本稿では, 1998 年パプア ニューギニア地震（Mw 7.1）により発生した津波を計算するために，波数分散項が入った線形 Boussinesq 式を陰的差分 法を用いて解く方法を開発し，津波の数值計算を行なった。比較のため，Imamura（1990）による方法を用いた計算も行 なった。房総沖の海底津波計での波形を比較した結果，津波波形，特に津波の後続波，を正確にモデルするためには線形 Boussinesq 式を使う必要がある事が分った。また，房総沖海底津波計で観測された津波は海嶺波と呼ばれる波で，伊豆・ 小笠原諸島近くの浅海を伝播しながら大きくなった波が，第 1 波より 1 時間近く遅れて観測されたたものである事が確認 された。 